\title{
ОПТИМІЗАЦІЯ СХЕМ ЗАМІСНОЇ ТЕРАПІЇ̈̈ ІМУНОГЛОБУЛІНАМИ ДЛЯ ВНУТРІШНЬОВЕННОГО ВВЕДЕННЯ ХВОРИХ НА В-КЛІТИННИЙ ХРОНІЧНИЙ ЛІМФОЦИТАРНИЙ ЛЕЙКОЗ/ЛІМФОМУ 3 МАЛИХ ЛІМФОЦИТІВ
}

\author{
Сергутіна С. Ю. ${ }^{1}$, Сівкович С. О. ${ }^{1}$, Рибальська А. П. ${ }^{1}$, Сербін I. М. ${ }^{2}$ \\ ${ }^{I}$ ДУ«Інститут гематології та трансфузіологї НАМН Украӥни», \\ Київ, Україна \\ ${ }^{2}$ КНП «Київська міська клінічна лікарня № 9», Київ, Украӥна
}

\begin{abstract}
Резюме
Вступ. Лікування хворих на В-клітинний хронічний лімфоцитарний лейкоз/ лімфому з малих лімфочитів (В-ХЛЛ/ЛМЛ) супроводжується високим ризиком виникнення інфекиійно-запальних ускладнень (ІЗУ). Проведення антибіотикотерапії для купірування ІЗУ при циих патологічних станах не завжди дозволяє ефективно контролювати інфекційний процес. Тому, для профілактики та лікування ІЗУ на тлі вторинних імунодефічитних станів у хворих на В-ХЛЛ/ЛМЛ все ширше застосовуються імуноглобуліни для внутрішньовенного введення (IГВВ).

Мета. Визначити критерї призначення та розробити алгоритм застосування препаратів ІГВВ у хворих на В-ХЛЛ/ЛМЛ.
\end{abstract}

Матеріали і методи. Для визначення критерїв призначення та алгоритму застосування замісної ІГВВ-терапії здійснено аналіз наукової літератури, анам. нестичних даних, а також проведено загальноклінічні, імунологічні та статистичні методи дослідження 62 хворих (30 чоловіків і 32 жінки) на В-ХЛЛ/ЛМЛ: 32 пацієнти із В-ХЛЛ, 30 - із В-клітинною ЛМЛ. Вік пацієнтів коливався від 25 до 80 р.

Результати. На основі проведених досліджень визначені критерії призначення замісної ІГВВ-терапї у хворих на В-ХЛЛ/ЛМЛ та розроблено алгоритм застосування IГВВ таким пацієнтам. Використання препаратів IГВВ за розробленим алгоритмом достовірно підвищувало концентрацію основних класів імуноглобулінів у сироватці крові хворих до фізіологічних значень. При цььому клінічно відмічали подовження ремісії у пачієнтів без виникнення випадків IЗУ або зниження їхньої частоти та тяжкості.

Висновки. Визначені критерії призначення IГВВ і розроблений алгоритм дозволив оптимізувати схеми застосування IГВВ у хворих на В-ХЛЛ/ЛМЛ.

Ключові слова: імуноглобуліни для внутрішньовенного введення (IГВВ), В-клітинний хронічний лімфочитарний лейкоз/ лімфома з малих лімфочитів, лікування IГВВ, критерії призначення IГВВ, алгоритм застосування IГВВ. 
Конфлікт інтересів: автори заявляють про відсутність конфлікту інтересів.

Фінансування: дослідження не мало спонсорської підтримки.

\title{
OPTIMIZATION OF INTRAVENOUS IMMUNOGLOBULIN REPLACEMENT THERAPY SCHEMES OF PATIENTS WITH B-CELL CHRONIC LYMPHOCYTIC LEUKEMIA/SMALL LYMPHOCYTIC LYMPHOMA
}

\author{
Serhutina S. Yu. ${ }^{1}$, Sivkovych S. O. ${ }^{1}$, Rybalska A. P. ${ }^{1}$, Serbin I. M. ${ }^{2}$ \\ ${ }^{1}$ SI «Institute of Haematology and Transfusiology of NAMS of Ukraine», \\ Kyiv, Ukraine \\ ${ }^{2}$ MNE «Kyiv City Clinical Hospital № 9», Kyiv, Ukraine
}

\begin{abstract}
Introduction. Treatment of patients with B-cell chronic lymphocytic leukemia/ small lymphocyte lymphoma (B-CLL/SLL) is associated with a high risk of infectious-inflammatory complications (IIC). Carrying out antibiotic therapy for relief of IIC in these pathological conditions doesn't always allow to effectively control the infectious process. Therefore, intravenous immunoglobulins (IVIG) are increasingly used for the prevention and treatment of IIC against secondary immunodeficiency in patients with $B$ $C L L / S L L$.

Aim. Determine the criteria for the appointment and develop an algorithm for the IVIG use in patients with $B-C L L / S L L$.

Materials and methods. To determine the criteria for prescribing and algorithm for the use of IVIG-therapy, an analysis of the scientific literature, anamnestic data, as well as general clinical, immunological and statistical methods of 62 patients (30 men and 32 women) on B-CLL/ SLL: 32 patients with B-CLL, 30 - with B-cell SLL. The age of patients ranged from 25 to 80 years.

Results. Based on the studies, the criteria for prescribing IVIG replacement therapy in patients with B-CLL/SLL were determined: 1) reduction of serum IgG content below 6,0 $\mathrm{g} / \mathrm{L} ; 2)$ the patient has a severe (according to WHO criteria) infectious-inflammatory complication (IIC) at least once a year or two less severe infectious cases in six months, caused not only by bacterial infection but also by the causative agent of viral etiology; 3) ineffective antibiotic therapy of IIC of bacterial etiology on the background of deep immunosuppression. Based on the results of the study, an algorithm for prescribing IVIG replacement therapy to patients with B-CLL/SLL was developed. The use of IVIG drugs according to the developed algorithm significantly increased the concentration of the main immunoglobulin classes in the serum of patients to physiological values: IgGfrom $(4,97 \pm 1,3) \mathrm{g} / \mathrm{L}$ to $(11,67 \pm 1,79) \mathrm{g} / \mathrm{L}(p<0,01) ; \operatorname{IgM}-$ from $(0,32 \pm 0,12) \mathrm{g} / \mathrm{L}$ to $(1,10 \pm 0,16) \mathrm{g} / \mathrm{L}(\mathrm{p}<0,001) ; \operatorname{IgA}-$ from $(0,34 \pm 0,17) \mathrm{g} / \mathrm{L}$ to $(1,73 \pm 0,28) \mathrm{g} / \mathrm{L}$ $(p<0,001)$. At the same time, clinically there was a prolongation of remission in patients without cases of IIC or a decrease in their frequency and severity.
\end{abstract}


Conclusions. The defined criteria for prescribing IVIG and the developed algorithm allowed to optimize the schemes of IVIG use in patients with B-CLL/SLL.

Keywords: intravenous immunoglobulins (IVIG), B-cell chronic lymphocytic leukemia/small lymphocytic lymphoma, IVIG therapy, criteria for the IVIG appointment, IVIG application algorithm.

\section{Вступ}

Однією з патогенетичних ознак В-клітинного хронічного лімфоцитарного лейкозу/лімфоми 3 малих лімфоцитів (В-ХЛЛ/ЛМЛ) $є$ зниження продукції імуноглобулінів (Ig) атиповими В-лімфоцитами [1]. В-лімфоцити при ХЛЛ/ЛМЛ внаслідок мутацій у клітинному геномі не розвиваються до плазматичних клітин і це призводить до різкого зменшення синтезу в організмі хворого Ig, до яких відносяться всі антитіла (АТ). У свою чергу, розвиток злоякісних неоплазій пригнічує функції нормальних клітин та індукує імунологічну недостатність і аутоімунні реакції внаслідок порушень функціонування гуморальної та клітинної ланок імунітету. Саме патологія гуморальної ланки імунітету (зниження синтезу АТ) відіграє провідну роль у виникненні інфекційно-запальних ускладнень (I3У) при В-ХЛЛ/ЛМЛ $[2,3]$. Крім того, сучасні протоколи лікування ВХЛЛ/ЛМЛ включають групу високоефективних цитостатичних препаратів, які, на жаль, призводять до вираженої имуносупресії [4, 5]. В умовах дисбалансу імунологічної реактивності головним завданням клініцистів $€$ корекція різних проявів вторинного (набутого) імунодефіциту, що може бути причиною виникнення ІЗУ у хворих на В-ХЛЛ/ЛМЛ. I саме задля профілактики і лікування гнійно-запальних процесів і вірусних інфекцій, що активізуються на тлі глибокої імуносупресії, широко використовуються препарати імуноглобулінів для внутрішньовенного введення (IГВВ) [6-8].

Слід зазначити, що в Україні замісна ІГВВ-терапія хворих на ХЛЛ здійснюється згідно 3 Додатком 3 до «Уніфікованого клінічного протоколу первинної, вторинної (спеціалізованої), третинної (високоспеціалізованої) медичної допомоги при ХЛЛ» (Наказ МО3 України від 12.05.2016 p. № 439 [9]. Відповідно до даного протоколу ІГВВ рекомендовано застосовувати хворим на ХЛЛ внутрішньовенно в дозі 0,4 г/кг кожні 3-4 тижні до досягнення рівня IgG 6-8 г/л. Проте, на нашу думку, недоліками даного протоколу є наступне: 1) не передбачено визначення ініціального рівня основних класів Ig у пацієнта із ХЛЛ; 2) не врахована необхідність визначення вмісту IgA у хворого та в препараті ІГВВ, що може призвести до анафілактичних реакцій після проведення замісної ІГВВ-терапії; 3) рекомендована тільки початкова доза препарату (0,4 г/кг) без урахування індивідуального рівня Ig у пацієнта; 4) корекція дози ІГВВ 
передбачена тільки після третього введення препарату при рекомендованій періодичності введення кожні 3-4 тижні.

Мета. Визначити критерії призначення та розробити алгоритм застосування препаратів ІГВВ у хворих на В-ХЛЛ/ЛМЛ.

\section{Матеріали і методи}

Для досягнення поставленої мети здійснено аналіз наукової літератури, анамнестичних даних, а також проведено загальноклінічні, імунологічні та статистичні методи дослідження 62 хворих (30 чоловіків і 32 жінки) з верифікованим діагнозом В-ХЛЛ/ЛМЛ: 32 пацієнти із В-ХЛЛ, 30 - із В-клітинною ЛМЛ. Усі хворі проходили обстеження і лікування у відділенні інтенсивної хіміотерапії ДУ «Інститут гематології та трансфузіологї НАМН України» (ДУ «ІГТ НАМН»; завідувач - д. мед. н., профеcop С. О. Сівкович) на базі гематологічного відділення № 1 Комунального некомерційного підприємства «Київська міська клінічна лікарня № 9». Середній вік пацієнтів складав $(62,14 \pm 1,41)$ р. (min -25 р., $\max -80$ р.). Дослідження виконані з дотриманням основних положень «Правил етичних принципів проведення наукових медичних досліджень за участю людини у якості об'єкта досліджень», затверджених Гельсінською декларацією Всесвітньої медичної асоціації (1964р.), International Council for Harmonisation of Good Clinical Practice (ICH GCP, 1996 p.), Наказу MO3 України від 23.09.2009 р. № 690 «Про затвердження Порядку проведення клінічних випробувань лікарських засобів та експертизи матеріалів клінічних випробувань і Типового положення про комісії з питань етики». Усі хворі на В-ХЛЛ/ЛМЛ були включені в клінічні дослідження на умовах інформованої згоди (протокол Комітету з медичної етики ДУ «ІГТ НАМН» від 26.06.2017 р. № 2). Обробку та аналіз отриманих результатів досліджень здійснювали 3 використанням математичних методів за допомогою пакету статистичних програм Statistica 6.1.

\section{Результати та їх обговорення}

Аналіз наукової літератури [10-15] показав, що основними критеріями призначення ІГВВ гематологічним хворим із вторинними (набутими) імунодефіцитами (у т. ч. при В-ХЛЛ/ЛМЛ) є наступні: 1) зниження вмісту IgG у крові пацієнта; 2) наявність тяжких або рецидивуючих бактеріальних інфекцій; 3) неефективне лікування антибіотиками; 4) доведена недостатність специфічних АТ.

Визначення вмісту основних класів Ig у сироватці крові пацієнтів $\epsilon$ обов'язковим лабораторним критерієм відбору для подальшого призначення ІГВВ-терапії. Вважається, що рівень вмісту IgG нижче 6,0 г/л 
слугує показником гіпогамаглобулінемії, проте застосування препаратів IГВВ, за рекомендаціями ВОО3 [12], необхідно розпочинати при вмісті $\operatorname{IgG}<4,0$ г/л. Згідно з деякими Національними керівництвами щодо застосування ІГВВ [13-15] у гематологічних хворих можливе призначення замісної ІГВВ-терапії при зменшенні рівня IgG нижче 5,0 г/л або 6,0 г/л. На сьогоднішній день проведеними дослідженнями доведено [6, 16-18], що випадки ІЗУ можуть виникати не обов'язково в усіх пацієнтів із ХЛЛ, але такі інфекції частіше трапляються, коли рівень IgG падає нижче 6,0 г/л. Тому, враховуючи дані наукової літератури та результати власних досліджень вмісту основних класів імуноглобулінів (IgG, IgA, IgM) у крові хворих на В-ХЛЛ/ЛМЛ, вважаємо, що призначення замісної терапії препаратами IГВВ необхідно здійснювати при рівні IgG у сироватці крові нижче 6,0 г/л для профілактики виникнення IЗУ на тлі проведення XT через імуносупресивну дію цитостатиків та іноді неефективне застосування супровідної терапії.

За даними Hallek et al. [19], не завжди нормальний рівень IgG у крові хворого є показником збереженості функціональної активності АТ, що може призводити до виникнення ІЗУ. Тому, відповідно до рекомендацій BOO3 та Національних керівництв деяких країн [12-15] другим критерієм для призначення замісної ІГВВ-терапії $є$ виникнення у пацієнта тяжкого бактеріального IЗУ (бактеріємії або сепсису, бактеріального менінгіту, остеомієліту/септичного артриту, бактеріальної пневмонії, вісцерального абсцесу) хоча б один раз на рік або двох менш тяжких інфекційних випадків за пів року (навіть при нормальному вмісті IgG). На нашу думку, доповненням до другого критерію для застосування препаратів ІГВВ у хворих на В-ХЛЛ/ЛМЛ $є$ не лише І3У, викликане бактеріальною інфекцією, але і збудником вірусної етіології. Це можна пояснити багатофункціональністю препаратів ІГВВ, які містять широкий спектр нормальних, поліклональних, поліспецифічних АТ, у тому числі і противірусних [20].

Третім критерієм призначення препаратів ІГВВ хворим на В-ХЛЛ/ЛМЛ може слугувати неефективна антибіотикотерапія при виникненні бактеріальних IЗУ на тлі глибокої імуносупресії. Цей критерій застосування ІГВВ є універсальним при призначенні замісної терапії даною групою препаратів. Тому, вважаємо обгрунтованим використання препаратів неспецифічних (поліфункціональних) ІГВВ при неефективості застосування антибіотиків для профілактики та лікування ІЗУ у хворих на В-ХЛЛ/ЛМЛ.

Відповідно до рекомендацій ВОO3 [12] четвертим критерієм призначення ІГВВ є доведена недостатність специфічних АТ. Так, за кордоном для профілактики та лікування цитомегаловірусної інфекції або при за- 
грозі інфікування вірусом гепатиту В для підвищення рівня специфічних АТ хворим застосовують специфічні (гіперімунні) ІГВВ, наприклад: Неоцитотект (5\% розчин), Цитотект (10\% розчин), Неогепатект (5\% розчин), Гепатект (10\% розчин); виробником даних препаратів $\epsilon$ «Biotest Pharma, GmbH», Німеччина. На жаль, через велику вартість специфічних IГВВ, нами не було використано дану групу препаратів у хворих на В-ХЛЛ/ЛМЛ при можливій недостатності специфічних цитомегаловірусних АТ або задля профілактики інфікування пацієнта вірусом гепатиту В при повторних гемотрансфузіях та ін.

При виконанні досліджень замісну ІГВВ-терапію було проведено 20 хворим на В-ХЛЛ/ЛМЛ відповідно до критеріїв призначення даної групи препаратів, що наведені вище, з урахуванням анамнезу захворювання і результатів імунологічних досліджень (визначення вмісту основних класів Ig (IgG, $\operatorname{IgM}, \operatorname{IgA})$ в сироватці крові пацієнта, показників клітинного імунітету). На основі проведених досліджень був розроблений алгоритм призначення препаратів ІГВВ хворим на В-ХЛЛ/ЛМЛ, який наведений на рис. 1.

Для проведення замісної ІГВВ-терапії використовували вітчизняні препарати Біовен моно ${ }^{\circledR}$ (5\% розчин) та Біовен ${ }^{\circledR}$ (10\% розчин) виробництва ТОВ «Фармацевтичний завод «Біофарма».

Згідно з розробленим алгоритмом, пацієнти із В-ХЛЛ/ЛМЛ, у яких рівень IgG в сироватці крові вище 6,0 г/л, але в анамнезі $є$ наявність IЗУ хоча б один раз на рік або двох менш тяжких інфекційних випадків за пів року, обов'язково потребують профілактичного застосування даної групи препаратів. Тому, двом хворим на В-ХЛЛ/ЛМЛ, у яких вміст IgG в сироватці крові був вищим за 6,0 г/л, але в анамнезі наявні І3У (пневмонія, плеврит) було проведено замісну ІГВВ-терапію. Це сприяло зменшенню проявів патологічного процесу при ІЗУ і поліпшенню стану пацієнтів. Вибір схеми застосування замісної ІГВВ-терапії та підбір препарату внутрішньовенного імуноглобуліну хворим на В-ХЛЛ/ЛМЛ з гіпоглобулінемією проводили індивідуально в залежності від вмісту основних класів Ig та обтяжувального анамнезу (наприклад, наявність супутньої патології, частота і тяжкість ІЗУ тощо). Застосування препаратів ІГВВ за розробленим алгоритмом:

а) достовірно підвищувало концентрацію основних класів імуноглобулінів у сироватці крові хворих до фізіологічних значень: $\operatorname{IgG}-3(4,97 \pm 1,13)$ г/л до $(11,67 \pm 1,79)$ г/л $(\mathrm{p}<0,01) ; \operatorname{IgM}-3(0,32 \pm 0,12)$ г/л до $(1,10 \pm 0,16)$ г/л $(\mathrm{p}<0,001) ; \operatorname{IgA}-3(0,34 \pm 0,17)$ г/л до $(1,73 \pm 0,28)$ г/л $(\mathrm{p}<0,001) ;$ 


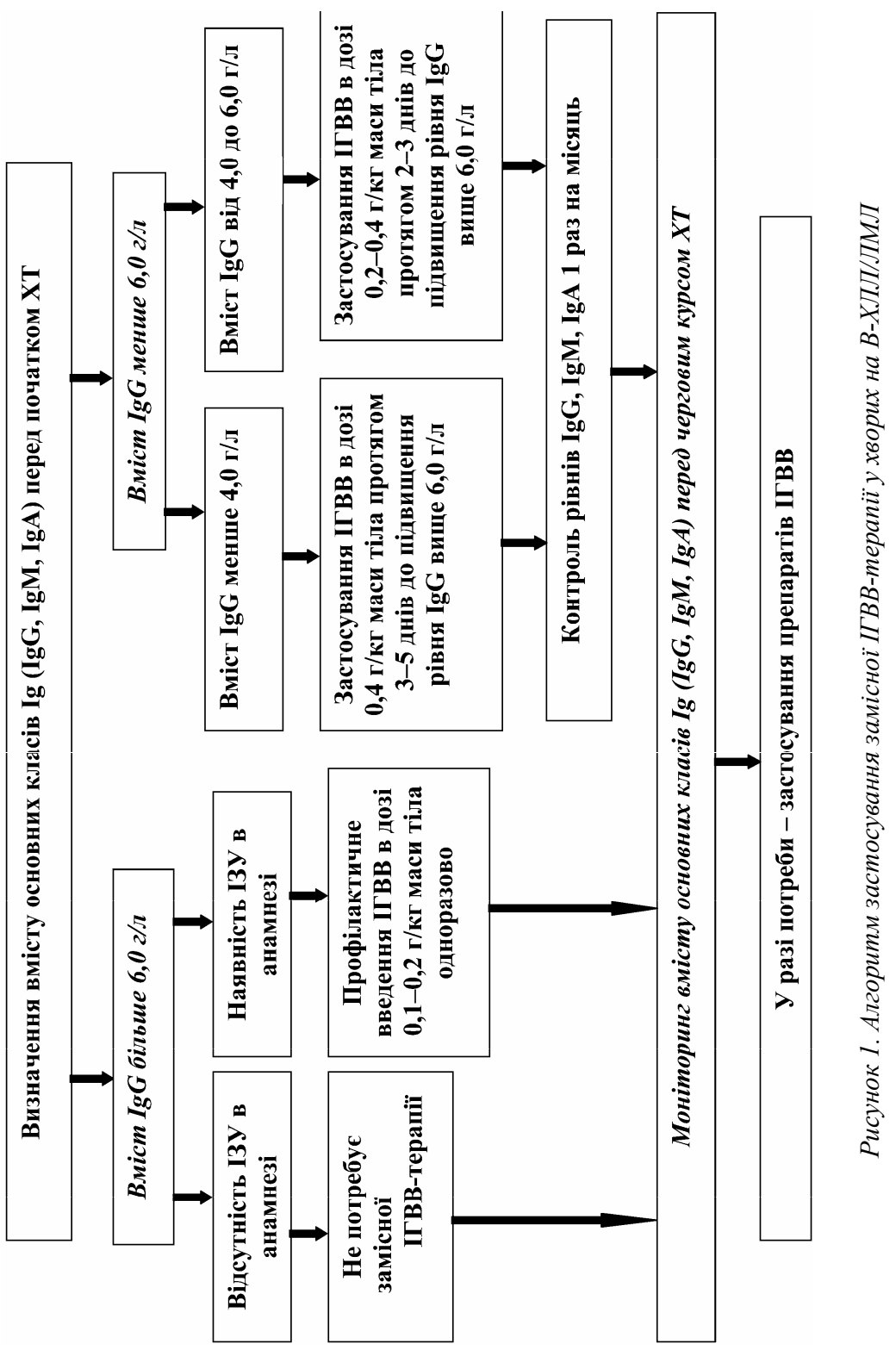


б) сприяло активації неспецифічної резистентності організму даної групи пацієнтів, стимулюючи функціональну активність нейтрофільних гранулоцитів (НГ): показники функціональної активності НГ після проведення ІГВВ-терапії перевищували аналогічні параметри практично здорових осіб та ініціальні значення до застосування препарату $(\mathrm{p}<0,05)$. При дослідженні концентрації цитокінів (інтерлейкіну-2, інтерферону-альфа та -гама) виявлено зміни продукції інтерлейкіну-2 - уповільнення його продукції після застосування IГВВ $(\mathrm{p}<0,001)$.

При цьому клінічно відмічали подовження ремісії у пацієнтів без виникнення випадків ІЗУ або зниження їхньої частоти та тяжкості.

Дослідження вмісту основних класів Ig після застосування ІГВВ в динаміці показало, що при одноразовому введенні препарату ІГВВ Біовен моно $^{\circledR}$ (5\% розчин) в дозі 0,2 г/л рівень $\operatorname{IgG}, \operatorname{IgM}$ та $\operatorname{IgA}$ підвищувався незначно і утримувався до 7-8 діб, а через 3 тижні їхній вміст становив майже такий, що був до проведення ІГВВ-терапії, іноді й нижче Навпаки, при застосуванні препарату Біовен ${ }^{\circledR}(10 \%$ розчин) рівень основних класів Ig зменшувався повільніше, особливо при неодноразових введеннях впродовж декількох днів (як зазначено в алгоритмі застосування ІГВВ). Це свідчить про те, що разове введення $5 \%$ розчину препарату ІГВВ в дозі 0,2 г/кг маси тіла не дає сталого лікувального ефекту і потребує тривалішого лікування ІГВВ правильно підібраною дозою.

\section{Висновки}

1. Критеріями призначення замісної терапії ІГВВ у хворих на В-ХЛЛ/ЛМЛ можуть слугувати: а) зниження вмісту IgG у сироватці крові нижче 6,0 г/л; б) виникнення у пацієнта тяжкого (за критеріями ВООЗ) інфекційно-запального ускладнення (ІЗУ) хоча б один раз на рік або двох менш тяжких інфекційних випадків за пів року, викликаних не тільки бактеріальною інфекцією, але і збудником вірусної етіології; в) неефективна антибіотикотерапія ІЗУ бактеріальної етіології на тлі глибокої імуносупресії.

2. За результатами дослідження розроблено алгоритм призначення замісної ІГВВ-терапії пацієнтам із В-ХЛЛ/ЛМЛ, який дозволив оптимізувати схеми застосування ІГВВ при даній патології. Застосування препаратів ІГВВ за розробленим алгоритмом достовірно підвищувало концентрацію основних класів імуноглобулінів в сироватці крові до фізіологічних значень і сприяло активації неспецифічної резистентності організму хворих на В-ХЛЛ/ЛМЛ. При цьому клінічно відмічали подовження ремісії у пацієнтів без виникнення випадків ІЗУ або зниження їхньої частоти та тяжкості. 


\section{Література}

1. Strati P, Shanafelt TD. Monoclonal B-cell lymphocytosis and early-stage chronic lymphocytic leukemia: diagnosis, natural history, and risk stratification. Blood. 2015;126(4):454-62.

DOI: $10.1182 /$ blood-2015-02-585059

2. Kipps TJ, Stevenson FK, Wu CJ, Croce CM, Packham G, Wierda WG et al. Chronic lymphocytic leukaemia. Nat Rev Dis Primers. 2017; 3:16096. DOI: 10.1038/nrdp.2016.96

3. Eichhorst B, Robak T, Montserrat E, Ghia P, Niemann CU, Kater AP et al. Chronic lymphocytic leukaemia: ESMO Clinical Practice Guidelines for diagnosis, treatment and followup. Ann. Oncol. 2015;26(5):78-84.

4. De Angelis F, Tosti ME, Capria S, Russo E., D'Elia GM, Annechini G, Stefanizzi C et al. Risk of secondary hypogammaglobulinaemia after rituximab and fludarabine in indolent non-Hodgkin lymphomas: a retrospective cohort study. Leuk. Res. 2015; 39(12):1382-8.

DOI: 10.1016/j.leukres.2015.10.013

5. Hilal T, Gea-Banacloche JC, Leis JF Chronic lymphocytic leukemia and infection risk in the era of targeted therapies: Linking mechanisms with infections. Blood. Rev. 2018;32(5): 387-99.

DOI: $10.1016 /$ j.blre.2018.03.004

6. Lachance S, Christofides AL, Lee JK, Sehn LH, Ritchie BC, Shustik C et al. A Canadian perspective on the use of immunoglobulin therapy to reduce infectious complications in chronic lymphocytic leukemia. Cur. Oncology. 2016;23(1):42-51.

DOI: $10.3747 / \operatorname{co} .23 .2810$

\section{References}

1. Strati P, Shanafelt TD. Monoclonal B-cell lymphocytosis and early-stage chronic lymphocytic leukemia: diagnosis, natural history, and risk stratification. Blood. 2015;126(4):454-62.

DOI: 10.1182/blood-2015-02-585059

2. Kipps TJ, Stevenson FK, Wu CJ, Croce CM, Packham G, Wierda WG et al. Chronic lymphocytic leukaemia. Nat Rev Dis Primers. 2017; 3:16096. DOI: 10.1038/nrdp.2016.96

3. Eichhorst B, Robak T, Montserrat E, Ghia P, Niemann CU, Kater AP et al. Chronic lymphocytic leukaemia: ESMO Clinical Practice Guidelines for diagnosis, treatment and followup. Ann. Oncol. 2015;26(5):78-84.

4. De Angelis F, Tosti ME, Capria S, Russo E., D’Elia GM, Annechini G, Stefanizzi C et al. Risk of secondary hypogammaglobulinaemia after rituximab and fludarabine in indolent non-Hodgkin lymphomas: a retrospective cohort study. Leuk. Res. 2015; 39(12):1382-8.

DOI: 10.1016/j.leukres.2015.10.013

5. Hilal T, Gea-Banacloche JC, Leis JF Chronic lymphocytic leukemia and infection risk in the era of targeted therapies: Linking mechanisms with infections. Blood. Rev. 2018;32(5): 387-99.

DOI: 10.1016/j.blre.2018.03.004

6. Lachance S, Christofides AL, Lee JK, Sehn LH, Ritchie BC, Shustik C et al. A Canadian perspective on the use of immunoglobulin therapy to reduce infectious complications in chronic lymphocytic leukemia. Cur. Oncology. 2016;23(1):42-51.

DOI: $10.3747 / \operatorname{co} .23 .2810$ 
7. Sánchez-Ramón S, Dhalla F, Chapel H. Challenges in the Role of Gammaglobulin Replacement Therapy and Vaccination Strategies for Hematological Malignancy. Front. Immunol. 2016; 7:317.

DOI: 10.3389/fimmu.2016.00317

8. Agostini C, Blau IW, Kimby E, Plesner T. Prophylactic immunoglobulin therapy in secondary immune deficiency - an expert opinion. Expert Rev. Clin. Immunol. 2016; 12(9):921-6.

DOI: 10.1080/1744666X. 2016.1208085

9. Про затвердження та впровадження медико-технологічних документів зі стандартизації медичної допомоги при хронічному лімфоїдному лейкозі : Наказ 12.05.2016 p. № 439 від 12.05.2016 р. № 439.

10. Anderson D, Ali K, Blanchette V, Brouwers M, Couban S, Radmoor P et al. Guidelines on the Use of Intravenous Immune Globulin for Hematologic Conditions. Transfus. Med. Rev. 2007;21(1):9-56.

DOI: 10.1016/j.tmrv.2007.01.001

11. Criteria for the clinical use of intravenous immunoglobulin in Australia : $2^{\text {nd }}$ edition. $2012.276 \mathrm{p}$.

12. WHO Guideline on core SmPC for human normal immunoglobulin for intravenous administration (IVIg). European Medicines Agency, 2018. 14 p.

13. Criteria for the Clinical Use of Immune Globulin : $1^{\text {st }}$ edition. Alberta Ministry of Health, Shared Health Manitoba, and Saskatchewan Ministry of Health; 2018. $61 \mathrm{p}$.

14. Clarke A, Levine TD, Ness S, Perez EE, Robins EH, Schleis T et al. Immunoglobulin Therapy Standarts of Practice: Clinical Guidelines and Implementation. N.-Y., 2018.8 p.
7. Sánchez-Ramón S, Dhalla F, Chapel H. Challenges in the Role of Gammaglobulin Replacement Therapy and Vaccination Strategies for Hematological Malignancy. Front. Immunol. 2016; 7:317.

DOI: 10.3389/fimmu.2016.00317

8. Agostini C, Blau IW, Kimby E, Plesner T. Prophylactic immunoglobulin therapy in secondary immune deficiency - an expert opinion. Expert Rev. Clin. Immunol. 2016; 12(9):921-6.

DOI: 10.1080/1744666X. 2016.1208085

9. [About the statement and introduction of medical and technological documents on standardization of medical care at chronic lymphoid leukemia: the Order of the Ministry of Health of Ukraine from 12.05.2016 № 439]. Ukrainian.

10. Anderson D, Ali K, Blanchette V, Brouwers M, Couban S, Radmoor P et al. Guidelines on the Use of Intravenous Immune Globulin for Hematologic Conditions. Transfus. Med. Rev. 2007;21(1):9-56. DOI: $10.1016 /$ j.tmrv.2007.01.001

11. Criteria for the clinical use of intravenous immunoglobulin in Australia : $2^{\text {nd }}$ edition. 2012. $276 \mathrm{p}$.

12. WHO Guideline on core SmPC for human normal immunoglobulin for intravenous administration (IVIg). European Medicines Agency, 2018. 14 p.

13. Criteria for the Clinical Use of Immune Globulin : $1^{\text {st }}$ edition. Alberta Ministry of Health, Shared Health Manitoba, and Saskatchewan Ministry of Health; 2018. $61 \mathrm{p}$.

14. Clarke A, Levine TD, Ness S, Perez EE, Robins EH, Schleis T et al. Immunoglobulin Therapy Standarts of Practice: Clinical Guidelines and Implementation. N.-Y., 2018.8 p. 
15. Updated Commissioning Criteria for the use of therapeutic immunoglobulin (Ig) in immunology, haematology, neurology and infectious diseases in England. January 2019. Immunoglobulin Commissioning Guidelines V1.3 Feb 2019.

16. Ueda M, Berger M, Gale RP, Lazarus HM. Immunoglobulin therapy in hematologic neoplasms and after hematopoietic cell transplanttation. Blood Reviews. 2018; 32(2):106-15. DOI: 10.1016/j.blre.2017.09.003.

17. Hallek M. Chronic lymphocytic leukemia: 2017 update on diagnosis, risk stratification, and treatment. Am. J. Hematol. 2017; 92(9):946-65. DOI: 10.1002/ajh.24826

18. Spaner DE, Venema R, Huang J, Norris P, Lazarus A, Wang G et al. Association of blood IgG with tumor necrosis factor-alpha and clinical course of chronic lymphocytic leukemia. EBioMedicine. 2018; 35:22232. DOI: 10.1016/j.ebiom.2018.08.045

19. Hallek M, Cheson BD, Catovsky D, Caligaris-Cappio F, Dighiero G, Döhner $\mathrm{H}$ et al. iwCLL guidelines for diagnosis, indications for treatment, response assessment, and supportive management of CLL. Blood. 2018; 131(25):2745-60.

DOI: $10.1182 /$ blood-2017-09-806398

20. Тимченко АC, Сергутіна СЮ. Імуноглобуліни для внутрішньовенного введення: проблеми та перспективи використання при лікуванні захворювань системи крові (огляд літератури і власні дослідження). Журнал НАМН України. 2019;25(1):63-70.

Надійшла: 01.06.2021

Контакти: sv.sergutina@gmail.com
15. Updated Commissioning Criteria for the use of therapeutic immunoglobulin (Ig) in immunology, haematology, neurology and infectious diseases in England. January 2019. Immunoglobulin Commissioning Guidelines V1.3 Feb 2019.

16. Ueda M, Berger M, Gale RP, Lazarus HM. Immunoglobulin therapy in hematologic neoplasms and after hematopoietic cell transplanttation. Blood Reviews. 2018; 32(2):106-15. DOI: 10.1016/j.blre.2017.09.003.

17. Hallek M. Chronic lymphocytic leukemia: 2017 update on diagnosis, risk stratification, and treatment. Am. J. Hematol. 2017; 92(9):946-65. DOI: 10.1002/ajh.24826

18. Spaner DE, Venema R, Huang J, Norris $\mathrm{P}$, Lazarus A, Wang $\mathrm{G}$ et al. Association of blood IgG with tumor necrosis factor-alpha and clinical course of chronic lymphocytic leukemia. EBioMedicine. 2018; 35:22232. DOI: 10.1016/j.ebiom.2018.08.045

19. Hallek M, Cheson BD, Catovsky D, Caligaris-Cappio F, Dighiero G, Döhner $\mathrm{H}$ et al. iwCLL guidelines for diagnosis, indications for treatment, response assessment, and supportive management of CLL. Blood. 2018; 131(25):2745-60.

DOI: $10.1182 /$ blood-2017-09-806398

20. Tymchenko AS, Serhutina SYu. [Intravenous immunoglobulins: problems and prospects of use in the treatment of diseases of the blood system (literature review and own research)]. Zhurnal NAMN Ukrainy. 2019;25(1):63-70. Ukrainian. 